\title{
Upaya Meningkatkan Kemampuan Perencanaan Karir Melalui Layanan Informasi Dengan Penggunaan Media Audio Visual Pada Siswa Kelas XI SMK Kesehatan Borneo Bhakti Husada Palangka Raya
}

\author{
Lisah', Merson U. Sangalang ${ }^{2}$ \\ Prodi BK FKIP Universitas Palangkaraya \\ E-mail: lisah.2902@gmail.com
}

\begin{abstract}
ABSTRAK
Perencanaan karier (career planning) adalah suatu proses dimana individu dapat mengidentifikasi dan mengambil langkah-langkah untuk mencapai tujuan- tujuan karir. Penelitian ini bertujuan untuk mengetahui efektifitas layanan informasi dengan penggunaan Media Audio Visual untuk meningkatkan perencanaan karir pada siswa kelas XI di SMK Kesehatan Borneo Bhakti Husada Palangka Raya. Penelitian yang digunakan adalan penelitian true eksperiment dengan pretest-posttest group control desain. Populasi penelitian ini berjumlah 37 (tiga puluh tujuh) siswa dengan sampel 12 (dua belas) siswa yang ditentukan dengan teknik purposive sampling. Teknik pengumpulan data pada penelitian ini menggunakan wawancara, observasi dan angket. Teknik analisis data menggunakan Uji-T berpasangan. Dari hasil penelitian yang telah dilakukan diperoleh skor hasil pretest 56,5 dan skor posttest $8 \mathrm{I}, 5$ dengan peningkatan skor sebesar 25. Hal ini membuktikan bahwa adanya peningkatan antara skor pretest dan posttest. Dari hasil penelitian yang telah dilakukan hasil uji hipotesis menggunakan rumus uji-t berpasangan untuk membuktikan hipotesis pada taraf kesalahan 0,05 jika $t$ hitung $>t_{\text {tabel }}$ pada $d b \mathrm{n}$ - I diketahui bahwa $t_{\text {hitung }}=-68,465$ dan $t_{\text {tabel }}=-2,57 \mathrm{I}$. Ini berarti $t$ hitung $>t_{\text {tabel }}$ maka $H_{\circ}$ ditolak dan $H_{a}$ diterima Hasil tersebut menunjukkan bahwa Layanan informasi Dengan Penggunaan Media Audio Visual efektif untuk Meningkatkan Perencanaan Karir Siswa kelas XI SMK Kesehatan Borneo Bhakti Husada Palangka Raya.
\end{abstract}

Kata Kunci: layanan informasi; media audio visual; perencanaan karir

\section{Efforts to Improve Career Planning Ability Through Information Services Using Audio Visual Media in Class XI Students of SMK Kesehatan Borneo Bhakti Husada Palangka Raya}

\begin{abstract}
Career planning is a process by which individuals can identify and take steps to achieve career goals. This study aims to determine the effectiveness of information services using Audio Visual Media to improve career planning in class XI students at SMK Kesehatan Borneo Bhakti Husada Palangka Raya. The research used was a true experimental study with a pretest-posttest control group design. The population of this study amounted to 37 (thirty seven) students with a sample of 12 (twelve) students determined by purposive sampling technique. Data collection techniques in this study used interviews, observations and questionnaires. The data analysis technique used paired T-test. From the results of the research that has been done, the pretest score is 56.5 and the posttest score is 81.5 with an increase in score of 25 . This proves that there is an increase between pretest and posttest scores. From the results of the research that has been carried out the results of hypothesis testing using the paired t-test formula to prove the hypothesis at an error level of 0.05 if $t$ count $>$ ttable on $d b n-I$ it is known that tcount $=-68.465$ and ttable $=-2.57 \mathrm{I}$. This means that $t$ count $>t$ table, then $\mathrm{Ho}$ is rejected and $\mathrm{Ha}$ is accepted. These results indicate that information services with the use of audio visual media are effective for improving career planning for XI grade students of SMK Kesehatan Borneo Bhakti Husada Palangka Raya.
\end{abstract}

Keywords: information services; audio visual media; career planning 


\section{PENDAHULUAN}

Pendidikan secara umum adalah segala upaya yang di rencanakan untuk mempengaruhi orang lain, baik individu, kelompok, maupun masyarakat sehingga mereka melakukan apa yang di harapkan oleh pelaku pendidikan. Seorang Guru BK dalam melakukan tugas profesionalnya, selalu di hadapkan pada banyak masalah yang harus di selesaikan. Dalam dunia pendidikan, terutama dalam kegiatan belajar, kelangsungan dan keberhasilan peserta didik dalam belajar, bukan hanya dipengaruhi oleh faktor intelektual saja, melainkan juga oleh faktor-faktor non intelektual yang tidak kalah penting dalam menentukan hasil belajar seseorang maupun peserta didik, salah satunya adalah untuk meningkatkan kemampuan perencanaan karirnya.

Perencanaan karir diartikan sebagai proses yang dilalui sebelum melakukan pemilihan karir. Winkel \& Hastuti (dalam Atmaja, 20/4) mengemukakan bahwa perencanaan karir tidak hanya sebagai proses yang dilalui sebelum memilih karir tapi juga sebagai proses menyeleksi tujuan karier dan arus karir untuk mencapai tujuan yang hendak dicapainya. Fitri et al (202I) menemukakan bahwa perencanaan karir adalah sesuatu yang menyangkut masa depan dalam jangka panjang yang harus direncanakan sejak jauh hari atau merencanakan kemana seseorang ingin melangkah dan apa yang ingin dicapai. Slmamora (dalam Yulia et al., 202I) mengemukakan bahwa perencanaan karier (career planning) adalah suatu proses dimana individu dapat mengidentifikasi dan mengambil langkah-langkah untuk mencapai tujuantujuan karir. Yusuf (dalam Fatmawati, 2015) menyebutkan ciri-ciri seseorang yang memiliki perencanaan karir adalah mengetahui cara memilih program studi, mempunyai motivasi untuk mencari informasi tentang karir, dapat memilih pekerjaan yang baik sesuai dengan bakat, minat, dan kemampuan, mampu memilih perguruan tinggi setelah sekolah. Dari berbagai pendapat di atas dapat disimpulkan bahwa perencanaan karir merupakan proses seleksi, perencanaan, pencarian informasi serta mengetahui cara mencapai karir/pekerjaan/pendidikan lanjutan yang disesuaikan dengan potensi yang dimiliki.

Berdasarkan observasi dan wawancara peneliti kepada Guru BK dan siswa kelas XI selama saya PPL (Praktik Pengalaman Lapangan) di SMK Kesehatan Borneo Bhakti Husada, beberapa siswa masih banyak kebingungan dalam menentukan kariernya walaupun mereka sudah mempunyai jurusan masing-masing di sekolah tersebut tetapi mereka masih tidak tau dengan kelanjutan kariernya di masa depan. Berdasarkan hasil wawancara diketahui sebagian siswa kelas XI mengeluh dengan jurusan yang dipilihnya karena merasa tidak cocok dengan jurusan yang di pilihnya, hal ini di sebabkan karena pada saat memilih jurusan masih di tentukan oleh orang tuanya. Selain masih bingung terhadap pemilihan karir setelah lulus SMK nanti. Layanan BK yang diberikan untuk meningkatkan pemahaman dan mengembangkan perencanaan karir tersebut kurang efektif. Hal tersebut dikarenakan guru BK hanya memberikan layanan dengan materi tentang pribadi dan sosial tetapi pemberian materi tentang karir tidak pernah diberikan. Dampak yang terjadi membuat sebagian besar dari mereka belum memiliki perencanaan karir untuk dirinya sendiri, sehingga dari semua itu membuat minimnya ketrampilan mereka sehingga mempengaruhi ketika mereka magang nanti. Apalagi di tambah dengan kurangnya pengetahuan informasi tentang dunia kerja semakin membuat kemampuan perencanaan karir siswa-siswi makin rendah. 
Penelitian ini bertujuan untuk mengetahui peningkatan perencanaan karir melalui layanan informasi dengan penggunakan media Audio Visual dalam meningkatkan kemampuan perencanaan karir pada siswa kelas XI SMK Kesehatan Borneo Bhakti Husada Palangka Raya, Dengan rincian sebagai berikut: (I) untuk mengetahui peningkatan perencanaan karir melalui layanan informasi dengan penggunakan media Audio Visual dalam motivasi untuk mencari informasi tentang karir pada siswa kelas XI SMK Kesehatan Borneo Bhakti Husada Palangka Raya. (2) untuk mengetahui peningkatan perencanaan karir melalui layanan informasi dengan penggunakan media Audio Visual dalam memilih pekerjaan yang sesuai dengan bakat, minat dan kemampuan pada siswa kelas XI SMK Kesehatan Borneo Bhakti Husada Palangka Raya. (3) untuk mengetahui peningkatan perencanaan karir melalui layanan informasi dengan penggunakan media Audio Visual dalam memilih program studi di perguruan tinggi pada siswa kelas XI SMK Kesehatan Borneo Bhakti Husada Palangka Raya. (4) untuk mengetahui peningkatan perencanaan karir melalui layanan informasi dengan penggunakan media Audio Visual dalam memilih perguruan tinggi pada siswa kelas XI SMK Kesehatan Borneo Bhakti Husada Palangka Raya.

Menurut Saputra \& Setianingrum (2016) Bimbingan adalah proses pemberian bantuan yang dilakukan oleh orang yang ahli kepada seseorang atau beberapa orang individu, baik anak-anak, remaja, maupun dewasa agar orang-orang yang dibimbing dapat mengembangkan kemampuan dirinya sendiri dan mandiri, dengan memanfaatkan kekuatan individu dan sarana yang ada dan dapat dikembangkan berdasarkan norma-norma yang berlaku. Prayitno \& Amti (dalam Ardi et al., 20I3) mengemukakan konseling adalah proses pemberian bantuan yang dilakukan melalui wawancara konseling oleh seorang ahli (disebut Konselor) kepada individu yang sedang mengalami suatu masalah (disebut klien) yang bermuara pada teratasinya masalah yang dihadapi klien. Dapat dismpulkan bahwa Bimbingan dan Konseling adalah proses pemberian bantuan yang dilakukan melalui wawancara konseling oleh konselor kepada konseli yang bermuara pada teratasinya masalah yang dihadapi konseli serta dapat memanfaatkan berbagai potensi yang dimiliki dan sarana yang ada sehingga individu atau kelompok itu dapat memahami dirinya sendiri untuk mencapai perkembangan yang optimal, mandiri serta dapat merencanakan masa depan yang lebih baik untuk mencapai kesejahteraan hidup.

Menurut Winkel dalam ((iriastuti, 202I) menyatakan bahwa "Layanan informasi merupakan suatu layanan yang berupaya memenuhi kekurangan individu akan informasi yang mereka perlukan”. Lebih lanjut Putri \& Sari (2018)mengemukakan layanan informasi, yaitu layanan yang membantu peserta didik menerima dan memahami berbagai informasi diri, sosial, belajar, karier/jabatan dan pendidikan lanjutan”. Kebutuhan informasi biasanya didorong oleh situasi problematik yang terjadi dalam diri manusia pada lingkungan internalnya, yang dirasakan tidak memadai. Berdasarkan pendapat beberapa ahi diatas maka dapat disimpulkan layanan informasi adalah suatu kegiatan atau usaha untuk membekali para siswa tentang berbagai macam pengetahuan supaya mereka mampu mengambil keputusan secara tepat dalam kehidupannya.

Menurut Sanjaya (dalam (Hayati \& Harianto, 2017) mendefinisikan Audio Visual adalah media yang mempunyai unsur suara dan unsur gambar diliat, misalnya rekaman video, berbagai ukuran film, slide 
suara, dan sebagainya. Menurut Wati (2019) mengemukaka Audio Visual merupakan salah satu media yang menampilkan unsur suara dan unsur gambar. Penggabungan kedua unsur inilah yang membuat Media Audio Visual memiliki kemampuan yang lebih baik. Dapat disimpulkan bahwa Audio visual merupakan sebuah alat bantu yang dipergunakan dalam pembelajaran untuk membantu tulisan dan kata yang diucapkan dalam penyampaian pengetahuan, sikap, dan ide dalam materi pembelajaran. Berdasarkan pendapat beberapa ahli diatas maka dapat disimpulkan bahwa Media Audio Visual adalah media yang dapat dikatakan cukup efektif karena menggabungkan media audio (unsur suara) dan visual (unsur gambar) secara terpadu pada saat mengkomunikasikan pesan atau informasi. Pembelajaran yang menggunakan Media Audio Visual, jelas bercirikan pemakaian perangkat keras selama proses pembelajaran. Perangkat yang digunakan adalah mesin proyektor film, tape recorder, dan proyektor visual yang lebar.

Menurut Andyani et al., (2017) Kelebihan media audio visual gerak/film yaitu: I) film dapat menggambarkan suatu proses, misalnya proses pembuatan suatu keterampilan tangan dan sebagainya; 2) dapat menimbulkan kesan ruang dan waktu; 3) penggambarannya bersifat tiga dimensional; 4) suara yang dihasilkan dapat menimbulkan realita pada gambar dalam bentuk ekspresi murni; 5) dapat menyampaikan suara seorang ahli sekaligus melihat penampilannya; 6) kalau film dan video tersebut berwarna akan dapat menambah realita objek yang diperagakan; 7) dapat menggambarkan teori sains dan animasi. Kekurangan media audio visual gerak/film yaitu: I) film bersuara tidak dapat diselingi dengan keterangan-keterangan yang diucapkan sewaktu film diputar, penghentian pemutaran akan mengganggu konsentrasi audiens; 2) audiens tidak akan dapat mengikuti dengan baik kalau film diputar terlalu cepat; 3) apa yang telah lewat sulit untuk diulang kecuali memutar kembali secara keseluruhan; 4) biaya pembuatan dan peralatannya cukup tinggi dan mahal. Sanjaya (2012:109) berpendapat mengenai keuntungan menggunakan media audiovisual, yaitu: I) dapat memberikan pengalaman belajar yang tidak mungkin dapat dipelajari secara langsung; 2) memungkinkan belajar lebih bervariatif sehingga dapat menambah motivasi dan gairah belajar; 3) dapat berfungsi sebagai sumber belajar secara mandiri tanpa sepenuhnya tergantung pada kehadiran guru. Dengan penggunaan media audio visual yang diterapkan sebagai metode pada layanan informasi dalam upaya untuk meningkatkan perencanaan karir dilakukan untuk meningkat minat dan antusias siswa karena ditampilkan dengan video atau slide yang menarik.

\section{METODOLOGI}

Penelitian ini berlokasi di SMK Kesehatan Borneo Bhakti Husada Palangka Raya Tahun Ajaran 2018/2019 yang beralamat di jl. G.Obos XI . Gang Jintan Palangka Raya. Populasi dalam penelitian ini adalah peserta didik kelas XI SMK Kesehatan Borneo Bhakti Husada Palangka Raya. Penelitian ini merupakan penelitian eksperimen dengan bentuk desain true Eksperiment Designs yang merupakan dalam desain eksperimen Pretest-Posttest Control Group Design yang menjelaskan Control group Pretest-Posttest design yaitu desain penelitian yang terdapat pre-test sebelum diberi perlakuan dan posttest setelah diberi perlakuan. Dengan demikian dapat diketahui lebih akurat, karena dapat membandingkan sebelum dan sesudah diberi perlakuan (Sugiyono, 2018). Pelaksanaan penelitian ekeperimen ini meliputi tes awal (pre test), dan tes akhir (post test) yaitu untuk menguji hasil pelaksanaan 
melalui Media Audio Visual dan kemudian membandingkan hasil dari tes akhir dengan hasil tes awal sebelum pelaksanaan Media Audio Visual. Jadi kelompok peneliti menggunakan dalam penelitian 2 kelompok yaitu kelompok Eksperiment dan kelompok Control. Desain True eksperimen Pretest-Posttest Control Group Design.

Teknik pengambilan sampel dalam penelitian ini dilakukan dengan sampling purposive yaitu teknik penentuan sampel dengan pertimbangan tertentu, pertimbangan dalam penelitian ini bahwa sampel yang ingin diteliti hanya pada peserta didik yang kurang mampu dalam menentukan perencanaan karir masa depannya. Sehingga didapat sampel dalam penelitian ini berjumlah 6 orang peserta didik yang terdiri dari 5 orang perempuan dan I orang laki-laki.

Teknik Pengumpulan data yang digunakan dalam penelitian ini yaitu: Angket, Observasi, wawancara, dan Dokumentasi. Instrument penelitian yang digunakan dalam penelitian ini adalah angket meningkatkat perencanan karir yang dikembangkan peneliti sendiri berdasarkan teori yang ada. Angket dalam penelitian ini menggunakan model likert. Model skala likert biasanya terdiri dari 5 jawaban. Teknik analisis data dalam penelitian ini menggunakan statistic non parametris yang digunakan untuk menguji hipotesis kompratif rata-rata dua sampel bila datanya berbentuk interval atau ratio adalah menggunakan ttest.

\section{HASIL DAN PEMBAHASAN}

I)Tempat dilaksanakannya penelitian adalah di ruang kelas XI SMK Kesehatan Borneo Bhakti Husada Palangka Raya. SMK Kesehatan Borneo Bhakti Husada Palangka Raya adalah salah satu sekolah Kejuruan yang berbasis kesehatan yang terletak di jl.G.Obos XI. Gang Jintan Palangka Raya. 2) hasil data yang diperoleh melalui observasi dan wawancara kepada sebagian peserta didik terseber antara lain : (I) mereka masih bingung perencanaan karir itu apa. (2) mereka kurang mempunyai motivasi untuk perencanaan karir mereka. (3) mereka tidak mempunyai perencanaan karir.

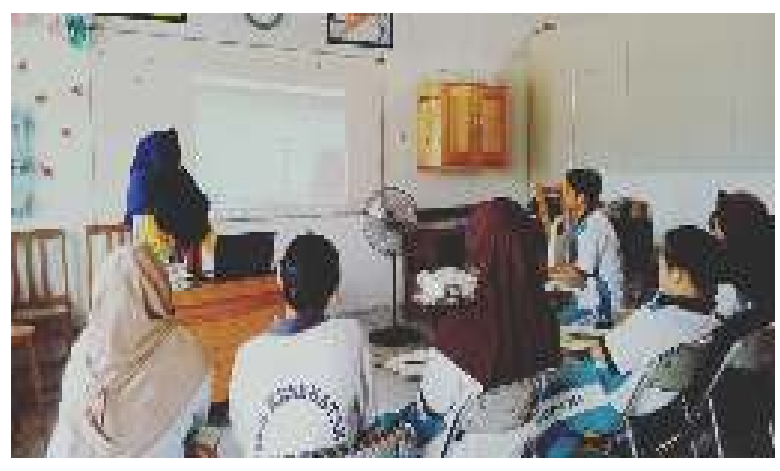

Gambar I Pemberian treatment layananan informasi dengan penggunaan Media Audio Visual

Hal ini sesuai dengan yang dikemukakan oleh Yusuf (dalam Fatmawati, 2015) menyebutkan seseorang yang memiliki perencanaan karir apabila memenuhi beberapa indikator yaitu : (I) Mengetahui cara memilih program studi. (2) Mempunyai motivasi untuk mencari informasi tentang karir. (3) Dapat memilih pekerjaan yang baik sesuai dengan bakat, minat, dan kemampuan, mampu memilih perguruan tinggi setelah sekolah. Hal ini sesuai dengan data hasil observasi dan wawancara bahwa 6 sampel tersebut mengalami rendahnya perencanaan karir, seperti yang terdapat pada indikator I, 2, dan 3. Jadi dari hasil wawancara dan observasi dengan peserta didik tersebut mengenai perencanaan karir menunjukkan bahwa perlu adanya pemberian layanan informasi dengan penggunaan Media Audio Visual kepada peserta didik. Hal ini dikarenan peserta didik kurang pengetahuan tentang perencanaam karir. 
Berikut ini data pre-tes dan post test dari hasil angket:

Tabel I. Rekapitulasi Data Pretest dan Posttest pada Kelompok Eksperiment

\begin{tabular}{cccccc}
\hline \multirow{2}{*}{ No. } & \multirow{2}{*}{ Subjek } & \multicolumn{2}{c}{ Pretest } & \multicolumn{2}{c}{ Posttest } \\
\cline { 3 - 6 } & & Skor & Kategori & Skor & Kategori \\
\hline I & A J & 53 & Rendah & 79 & Sedang \\
\hline 2 & AS & 54 & Rendah & 80 & Sedang \\
\hline 3 & CRS & 56 & Rendah & 81 & Sedang \\
\hline 4 & SH & 57 & Rendah & 82 & Sedang \\
\hline 5 & TW & 59 & Rendah & 83 & Sedang \\
\hline 6 & R W & 60 & Rendah & 84 & Sedang \\
\hline & Rata- & 56,5 & Rendah & $8 \mathrm{I}, 5$ & Sedang \\
& rata & & & & \\
\hline
\end{tabular}

Dari tabel I dapat dilihat dari hasil pretest dan post test pada kelompok eksperimen terjadi kenaikaran rata-rata sebesar 25 dari skor pre test $56.5 \mathrm{di}$ kategori rendah dan meningkat pada hasil angket post test di skor 8I,5 pada kategori sedang.

Tabel II. Rekapitulasi Data Pretest dan Posttest pada Kekompok Control

\begin{tabular}{cccccc}
\hline \multirow{2}{*}{ No. } & Subjek & \multicolumn{2}{c}{ Pretest } & & Posttest \\
\cline { 3 - 6 } & & Skor & Kategori & Skor & Kategori \\
\hline I & DP & 47 & Rendah & 55 & Rendah \\
\hline 2 & HH & 45 & Rendah & 56 & Rendah \\
\hline 3 & AB & 46 & Rendah & 60 & Rendah \\
\hline 4 & RP & 48 & Rendah & 61 & Rendah \\
\hline 5 & R & 49 & Rendah & 62 & Rendah \\
\hline 6 & VS & 50 & Rendah & 63 & Rendah \\
\hline & Rata- & 47,5 & Rendah & 59,5 & Rendah \\
& rata & & & & \\
\hline
\end{tabular}

Dari tabel II dapat dilihat dari hasil pretest dan post test pada kelompok kontrol terjadi kenaikaran ratarata sebesar 12 dari skor prestest 47,5 di kategori rendah dan meningkat pada hasil angket post test di skor 59,5 pada kategori rendah.
Selain itu, analisis data juga dilakukan dengan melihat 3 (tiga) indikator dari perencamaam karir dengan rinciannya sebagai berikut :

(I) Pada indikator Mempunyai motivasi untuk mencari informasi tentang karir dengan hasil pretest 45 dan hasil posttest 65, terjadi peningkatan 20 dengan kriteria sedang. (2) Pada indikator Dapat memilih pekerjaan yang sesuai dengan bakat, minat, dan kemampuan dengan hasil pretest 45 dan hasil posttest 64,6, terjadi peningkatan sebesar 19,6 dengan kriteria sedang. (3) Pada indikator Dapat memilih program studi di Perguruan Tinggi hasil pretest 45 dan hasil posttest 62,5 , terjadi peningkatan sebesar 17,5 dengan kriteria sedang. (4) Pada indikator Mampu memilih perguruan tinggi setelah sekolah Tinggi hasil pretest 45 dan hasil posttest sebesar 62,5, terjadi peningkatan sebesar 22 dengan kriteria sedang. Dari hasil penelitian yang telah dilakukan dan hasil uji hipotesis menggunakan rumus uji-t berpasangan untuk membuktikan hipotesis pada taraf kesalahan 0,05 jika t hitung $<t_{\text {tabel }}$ pada $d b \mathrm{n}$ - I diketahui bahwa $t_{\text {hitung }}=-68,465$ dan $t_{\text {tabel }}=-2,57 \mathrm{I}$. Ini berarti $t_{\text {hitung }}<t_{\text {tabel }}$ maka $H_{\circ}$ ditolak dan $\mathrm{H}_{\mathrm{a}}$ diterima. Sehingga dari hasil keseluruhan data dan tabel diatas dapat dilihat adanya peningkatan setelah diberikan layanan Informasi dengan Media Audio Visual pada masing-masing siswa mengalami peningkatan anatara hasil pretest dengan hasil posttest.

\section{KESIMPULAN}

Dapat disimpulkan bahwa layanan informasi dengan penggunaaan media audio visual terbukti efektif meningkatkan kemampuan perencanaan karir siswa terlihat dari hasil perbandingan rata-rata skor pretest dengan post-tes pada kelas eksperimen yang mengalami peningkatan skor sebesar 25. Selain itu, berdasarkan hasil t-test juga membuktikan bahwa 
keefektifitasan layanan media audio visual dalam meningkatkan kemampuan perecanaan karir siswa SMK Kesehatan Borneo Bhakti Husada Palangka Raya.

\section{REFERENSI}

Andyani, N., Saddhono, K., \& Mujyanto, Y. (20I7). Peningkatan kemampuan menulis teks eksplanasi dengan menggunakan media audiovisual pada siswa sekolah menengah pertama. Basastra, 4(2), $16|-| 74$.

Ardi, Z., Yendi, F. M., \& Ifdil, I. (20I3). Konseling Online: Sebuah Pendekatan Teknologi Dalam Pelayanan Konseling. Jurnal Konseling Dan Pendidikan, I(I), I. https://doi.org//0.29210/I I00

Atmaja, T. T. (20/4). Upaya meningkatkan perencanaan karir siswa melalui bimbingan karir dengan penggunaan media modul Psikopedagogia,

$3(2)$. https://core.ac.uk/download/pdf/324200484.pdf

Fatmawati, A. (2015). Pengembangan Media Blog Sebagai Sarana Informasi Untuk Meningkatkan Kemampuan Perencanaan Karir Di SMAN I Bulukumba. Jurnal Psikologi Pendidikan Dan Konseling: Jurnal Kajian Psikologi Pendidikan Dan Bimbingan Konseling, I(2), 163-169.

Fitri, A., Sari, F., ... F. P.-J. P., \& 202I, U. (202I). Penyuluhan Manajemen Sumber Daya Manusia Untuk Pengembangan Karir Pasca Kelulusan Sekolah SMK Pluit Raya Penjaringan Jakarta Utara.

Openjournal.Unpam.Ac.Id. http://openjournal.unpam.ac.id/index.php/JPDM/ article/view/ /349 |

Hayati, N., \& Harianto, F. (2017). Hubungan Penggunaan Media Pembelajaran Audio Visual dengan Minat Peserta Didik pada Pembelajaran Pendidikan Agama Islam di SMAN I Bangkinang Kota. Al-Hikmah: Jurnal Agama Dan IImu
Pengetahuan, 14(2), 160-180.

IRIASTUTI, M. A. E. E. (202I). LAYANAN INFORMASI UPAYA MENINGKATKAN KEDISIPLINAN MENGHADAPI PRAKTIK KERJA INDUSTRI DI SEKOLAH MENENGAH KEJURUAN. VOCATIONAL: Jurnal Inovasi Pendidikan Kejuruan, I(2), 8-15.

Putri, R. D., \& Sari, S. P. (20|8). Implementation of John Holland's Career Theory in Guidance and Counseling. ENLIGHTEN: Jurnal Bimbingan Konseling Islam, I(2), I26-I32.

Saputra \& Setianingrum. (2016). Perkembangan motorik halus anak usia 3-4 tahun di kelompokbermain cendekia kids school madiun dan implikasinya pada layanan konseling. Jurnal CARE. http://ejournal.unipma.ac.id/index.php/JPAUD/article/do wnload/536/480

Sugiyono. (2018). Metode Penelitian Kuantitatif,Kualitatif dan R\&D. In ke-26.

Wati, E. R. (2019). Ragam media pembelajaran.

Yulia, Y., Bunu, H. Y., Suriatie, M., del Lena, M., \& Samuda, R. (202I). Penerapan Teknik Modeling Simbolis Dalam Pengembangan Perencanaan Karier Siswa SMPN 6 Palangka Raya. As-Syar'i: Jurnal Bimbingan \& Konseling Keluarga, 3(2), 102 109. 